\title{
Kazakhstan \\ and the Eurasian \\ Economic Union
}

\section{From Integration to Political Hold-Up Strategy}

Roman A. Yuneman

\author{
Roman A. Yuneman \\ Higher School of Economics, Moscow, Russia \\ School of International Affairs \\ Postgraduate student \\ ORCID: 0000-0003-4006-2233 \\ ResearcherID: P-9338-2015 \\ E-mail: roman@yuneman.ru \\ DOI: $10.31278 / 1810-6374-2020-18-4-37-55$
}

\begin{abstract}
Since its early days, the Republic of Kazakhstan has been participating in all forms of Eurasian integration, yet in the last decade its integration policy has undergone significant changes. This article examines the evolution of Kazakhstan's foreign policy with regard to Eurasian integration. To disclose the reasons for it, the present study uses the foreign policy model of a rising power within the framework of an international institution. The results of the analysis make it possible to say that since 2009 Kazakhstan has made a transition from the strategy of investing into the development of Eurasian integration institutions to a strategy of extorting (hold-up) political and economic concessions. This transition was driven by the change in the balance of external opportunities for Kazakhstan-from unfavorable at the beginning of the integration process to favorable after 2014.
\end{abstract}

Keywords: Kazakhstan, Russia, the Eurasian Economic Union, integration, hold-up strategy, rising power, established power. 
tarting from the 1990s Kazakhstan's President Nursultan Nazarbayev repeatedly called for various forms of economic integration in the post-Soviet space. This course was driven by the objective interests of the newly independent republic economically connected with other countries, above all Russia, in the post-Soviet space. However, it was only in the early 2000s, after the creation of the Eurasian Economic Community (EurAsEC), that the ideas of Eurasian integration began to be translated into life. This time the role of the integration's driving force belonged to Russia (Mansurov, 2008).

It is noteworthy that throughout the search for the most effective forms of integration in the post-Soviet space, Kazakhstan has always been among the co-founders of almost all associations and unions: the Customs Union (CU), the Common Economic Space (CES), and the Eurasian Economic Union (EAEU), created in 2015. Moreover, in the 1990s, Astana attempted to create Kazakhstan-led sub-regional integration projects.

Nevertheless, Eurasian integration is often viewed from the standpoint of Russia's national interests when Moscow's policies along this track are in focus (Bordachev, 2015; Kusznir, 2015; Akimbekov, 2014). In this context, Kazakhstan often acts as a player of secondary importance in Eurasian integration.

Although Kazakhstan's foreign policy as such has been studied well enough, its Eurasian integration aspect enjoys relatively little attention (Malysheva, 2016; Isaacs, 2020; Sullivan, 2019; Kassen, 2018). Many view Kazakhstan's foreign policy from a constructivist point of view through the lens of the elites' perception of foreign policy, integration processes, or identity (Laruelle, 2015; Roberts, 2016; Heller, 2019; Libman, 2018; Anceschi, 2015). Some authors consider Eurasian integration as part of Kazakhstan's broader policy of counterbalancing large actors (Roberts, 2016; Nurgalieva, 2016; Clarke, 2015; Ambrosio, 2015). Those researchers who are focused entirely on integration often confine themselves to examining its exclusively economic component (Bhutia, 2019; Migranyan, 2019; Gusev, 2015).

In many of the above works the authors, one way or another, touch upon the evolution of Kazakhstan's policy in relation to Eurasian 
integration after 2014. However, the reasons for this evolution often remain largely unexplored. Usually, the authors pick only one factor for integration policy changes, but fail to present a comprehensive analysis of the diversity of reasons that could have influenced this change. For example, they may discuss solely the reasons related to the security of Kazakhstan's northern borders (Morozov, 2015; Holmquist, 2015) or the factors behind the soaring confrontation between Russia and the West, which indirectly affected Kazakhstan (Sullivan, 2019). None of Kazakhstan's foreign policy studies proposed a framework that would explain the country's policy in relation to Eurasian integration. In this work, we will try to eliminate this gap.

This article examines the evolution of Kazakhstan's foreign policy with regard to Eurasian integration during the creation and development of the main institutions of integration. The purpose of the study is to describe the above evolution starting from the creation of the Customs Union in 2009 to the present day, and to establish the reason for its change. For this purpose, the framework developed by Scott L. Kastner, Margaret M. Pearson and Chad Rector for analysis of China's foreign policy in international institutions (Kastner et al., 2016) has been used. In addition to analyzing the reasons for the change in Kazakhstan's foreign policy, this work verifies the possibility of using Kastner's model for explaining the integration processes at the regional level. This work relies on the assumption that starting from 2009 Kazakhstan has been turning away from the strategy of investment into the development of Eurasian integration institutions to a hold-up strategy of securing political and economic concessions as a result of the change in the balance of external opportunities-from unfavorable at the beginning of integration to favorable after 2014 .

\section{A MODEL FOR ANALYZING KAZAKHSTAN'S FOREIGN POLICY WITH REGARD TO EURASIAN INTEGRATION}

The model proposed by Scott L. Kastner, Margaret M. Pearson, and Chad Rector explains the foreign policy of a rising power within an international regime that is established or initiated by an established power (Kastner et al., 2016, p.143). Within the framework of this 
model, three rising power foreign policy strategies are distinguished: investment (invest), extortion (hold-up) and passive participation (accept), which depend on two variables: a balance of external options for a rising power and the extent to which the established power considers the rising power to be indispensable (perception of indispensability) for the existence of the regime. This model allows for determining which foreign policy strategy Kazakhstan uses during a certain period, and also for establishing the reasons that influenced the choice of this strategy.

Although the authors use this model to analyze China's foreign policy within the framework of international institutions, we believe that it can be employed for analyzing Kazakhstan's foreign policy in relation to Eurasian integration. First, the Kastner et al model examines the interaction of countries (China and the United States) within the framework of international regimes. The Eurasian Economic Union is also a regime in a broad sense, since it falls under its definition as an institution "possessing norms, decision rules, and procedures which facilitate a convergence of expectations" (Krasner, 1983). Some authors consider it to be an entity of different regimes, but even this approach leaves room for considering the EAEU a regime (Dragneva and Wolczuk, 2014).

Secondly, the above model analyzes the rising power's foreign policy in relation to the established power. If these concepts are to be considered within the framework of Eurasian integration, we believe that Kazakhstan can be rated as a rising power, and Russia as an established power. In the given model the rising power is understood as " $a$ country that in the past played a minor role in contributing to second-order cooperation on a particular issue but that is an increasingly consequential actor within that issue-area," while the established power is, respectively, the one that established the international regime (Kastner et al., 2016, p.147). Moreover, these concepts can be used not only in the global, but also in the regional context. Within the framework of integration in the post-Soviet space, Russia has been the leader of integration processes since the creation of the EAEU (and in the broad sense starting from the emergence of the Union State 
of Russia and Belarus), which is a reason enough to characterize it as an established power. Since the beginning of Eurasian integration, Kazakhstan has played an ever-increasing role for its successful expansion and deepening: without its participation, it would have been impossible to geographically expand Eurasian integration to the Central Asian states. All this makes it possible to characterize Kazakhstan as a rising power.

In accordance with the model used in this work, Kazakhstan has three main Eurasian integration-related foreign policy strategies. One is to accept, that is, to passively participate in international institutions. A state chooses such a strategy if the balance of external opportunities is favorable and the country is not perceived as indispensable (Kastner et al, 2016, p.143).

Another strategy is to invest. If the balance of external opportunities from non-participation in an international institution is unfavorable for a country, then it will prefer to actively invest into the development of this institution, often making political or economic concessions (Kastner et al., 2016, p.145).

Finally, there is the extortion (hold-up) strategy. If the balance of external opportunities is favorable and a country is perceived as indispensable for the successful functioning of an international institution, then it will prefer to demand political/economic concessions or changes to the "rules of the game" in exchange for participation in this institution (Kastner et al., 2016, p.143).

The authors of the model understand external opportunities as " $a$ government's expectation about what would happen if it were to stop cooperating with other states to promote or maintain a multilateral regime" (Kastner et al, 2016, p.147). At the same time, the state does not have to be interested in the collapse of the international regime; it usually uses the presence of these opportunities as leverage in negotiations (Kastner et al., 2016, p. 148). The model takes into account not only the presence of external opportunities for a rising power, but also their relation to the external opportunities of the established power, that is, a balance of these external opportunities. This variable can have two values: the balance of external opportunities can be favorable for a rising power or 
unfavorable. For instance, Kazakhstan's external opportunities stemming from non-participation in Eurasian integration may be unfavorable by themselves, but Russia's external opportunities may be still worse-so the "final" balance will be favorable for Kazakhstan.

The second variable is the perception of the rising power's indispensability from the standpoint of the established power for the successful functioning of an international institution. That is, the state can be viewed as dispensable or, conversely, indispensable. The authors of the model do not give an exhaustive list of reasons why a country can be considered indispensable, but argue that an indispensable rising power can use the opportunity to pull out from an international institution to gain a competitive edge in negotiations (Kastner et al., 2016, p.152).

Next, we will consider Kazakhstan's policy regarding Eurasian integration in 2009-2019, and also try to determine how the balance of external opportunities and Russia's perception of Kazakhstan as a participant in Eurasian integration changed on the basis of an analysis of economic statistics, actions by Kazakhstan and other foreign policy actors, as well as statements by Kazakhstan's top leadership. To do this, we will consider Kazakhstan's foreign policy in relation to Eurasian integration during two periods: 2009-2013 and 2014-2019.

\section{KAZAKHSTAN'S EURASIAN INTEGRATION POLICY IN 2009-2013}

Kazakhstan's interest towards Eurasian integration can be divided into two groups. First, economic goals. Russian economist L. Yu. Gusev identifies five main sub-goals: easier transit from China to Europe, inexpensive access to Russian pipelines, benefits from a unified energy system with Russia, the marketing of farm produce in Russia, and fasttracked modernization of the economy (Gusev, 2015, p. 95).

Second, there is a group of goals related to Kazakhstan's national security, above all the security of Kazakh oil and gas supplies to European markets (Nurgalieva, 2016, p.92). Energy exports are the most important sector of the Kazakh economy, for they account for up to $70 \%$ of the overall export and yield $40 \%$ of state budget revenues (Clarke, 2015). Even though Kazakhstan works hard to diversify the transit of hydrocarbons, up to $85 \%$ of all oil and gas is still exported 
through Russian pipelines (Laruelle, 2019, p. 215; Today.kz, 2015). Security concerns also include the risk of escalating tensions in the northern regions of Kazakhstan, where Russians constitute a significant ethnic minority. Some researchers argue that this is one of the main motives for any integration with Russia (Clarke, 2015).

Starting from the 1990s, and almost until the emergence of the EAEU, Nazarbayev repeatedly emphasized the need for creating a Eurasian Union (without the adjective economic), but later began to insist on an Economic Union (Rakhaev et al., 2014, p.19). Both in 1998 and 2008, Kazakhstan's president said that the yet-to-be created Customs Union would be just a prelude to a close economic, monetary, political and defense union, while stressing, however, that this would not lead to the loss of sovereignty (Mansurov, 2008, p.22). EAEU Secretary-General Tair Mansurov echoed him: "We must continue to build a common market, a single currency union, and only then declare that there should be not just the Eurasian economic community, but a Eurasian Union of States" (Rakhmatulina, 2010, p. 75). But, as integration deepened in the post-Soviet space, the original draft was gradually, at the will of the Kazakh and Belarusian sides, stripped of such components as supranational macroeconomic control or coordination of defense initiatives (Skriba, 2015, p. 100). The idea of a currency union, of which Kazakhstan was a supporter in the mid2000s, also vanished without a trace (Akimbekov, 2014).

This is a stark contrast to 2011, when Nazarbayev authored one of his key policy articles, entitled "The Eurasian Union: From an Idea to the History of the Future." In this article the author advocated the creation of not only a currency union, but also a Eurasian Assembly-a body of inter-parliamentary interaction, a program for technological and industrial cooperation, and the EAEU Chamber of Commerce (Nazarbaev, 2011). To back up his rhetoric about the common historical destiny and the brotherhood of nations, Nazarbayev pointed to the experience of the European Union as a reference point. He found it both positive and worth studying. That is, when the Customs Union was still in the making, the rhetoric of Kazakhstan's officials was pro-Eurasian and aimed at strengthening integration (including political in the near future). 
This was confirmed by the discussions over plans to create a common parliament for a future Eurasian Union (Akimbekov, 2014), and the initial intention to make decisions of the Eurasian Economic Commission - the main executive body of the union-mandatory for all member countries (Dragnewa and Wolczuk, 2014, p.12).

In 2010, for the sake of creating a Customs Union within the Eurasian Economic Union, Kazakhstan had to make certain concessions in the field of customs regulation. Kazakhstan's original import duties were lower than those of the other member-states, so with the introduction of the Unified Customs Tariff (the UCT) the national tariffs had to be raised to the Customs Union's level. Kazakhstan's average weighted average customs tariff went up more than 1.5 times from $6.2 \%$ to $10.6 \%$ (Rahmatulina, 2010, p.80). However, this was partially offset by better conditions for gas and oil transit to Europe through Russia (Skriba, 2015, p. 101), as well as more exemptions from the EAEU's UCT (Bagdasaryan and Pahomov, 2016, p.6).

\section{KAZAKHSTAN'S EURASIAN INTEGRATION POLICIES IN 2014-2019}

The Treaty on the Establishment of the Eurasian Economic Union was signed on May 29, 2014 amid the growing U.S.-Russia confrontation over Crimea's reunification with Russia. By the moment the treaty was signed, all political aspects of integration had been excluded from the agreement through the efforts of Kazakhstan and Belarus. Taken together, the following provisions, previously put forward by the leaders of the three countries (some of which had already been included in the preliminary draft document), were removed (Kheifets, 2015, p.7):

- Common citizenship and visa control;

- The protection of compatriots abroad (at Kazakhstan's request);

- Export control (as suggested by Kazakhstan);

- Creation of an inter-parliamentary assembly (dropped at Kazakhstan's initiative);

- Close military-technical cooperation (Kazakhstan was behind aborting this provision, too);

- Progress towards the creation of a currency union. 
The agreement on the creation of the EAEU did not contribute anything entirely new, except for a new name, to the integration processes in the post-Soviet space. Two chapters of the EAEU agreement's total four are exact replicas of those found in the agreements on the CU and the CES (the 2014 Treaty). Moreover, the treaty itself actually implies finalizing the creation of an actual customs union, obliging the member states to reach an agreement on oil, gas and finance by 2025 (Knobel, 2015, p.88).

The official discourse of the Kazakh authorities has also changed. Despite the fact that Russia continued to be referred to as a strategic ally, proposals for political integration disappeared from public speeches by Kazakhstan's top officials. Instead, there followed warnings that Kazakhstan would quit the EAEU, if its sovereignty were at risk (Nazarbaev, 2014). In the official Foreign Policy Concept of the Republic of Kazakhstan for 2014-2020, the Chinese project of the Silk Road Economic Belt and the U.S. project of the New Silk Road and association with the EU began to be regarded as alternatives to Eurasian integration (Concept, 2014).

During this period, Astana continued its multi-vector policy in the economic sphere. For example, Kazakhstan, separately from the EAEU and Russia, was negotiating with China its involvement in the Economic Silk Road project. Also, in 2015, following negotiations in Istanbul, Kazakhstan joined an international consortium for the transportation of goods from China to Europe, using routes bypassing Russia (Turkey and China, 2015). Also, in 2015, Kazakhstan signed a new cooperation and partnership agreement with the European Union (Malysheva, 2016).

Astana's so-called "trade wars" on Russian imports were a clear sign Kazakhstan's elites were unhappy about the progress of the Eurasian integration project. Growing supplies of Russian goods to the domestic market of Kazakhstan undermined the competitiveness of domestic production (mainly agricultural) (Kheifets, 2015, p.16). This problem became especially acute in 2015 , when, due to the devaluation of the Russian ruble, low-price Russian goods started pouring into Kazakhstan. In 2015, the Kazakh leadership introduced a ban on the import of not only certain types of food products from Russia, but 
also Russian oil products (Kheifets, 2015, p.16). It is also noteworthy that Kazakhstan has not joined Russia's food counter-sanctions, which contradicts the principles of the EAEU common market.

Over time, Astana's attitude towards the accession of new members to the EAEU also changed. Kazakhstan opposed the idea of Armenia and Kyrgyzstan joining the EAEU (Rakhaev et al., 2015, p.22). Firstly, tensions with Kyrgyzstan might have occurred due to illegal Kyrgyz migration into Kazakhstan, dumping policies by Kyrgyz agricultural producers, as well as Chinese propaganda that triggered conflicts between Nur-Sultan and Bishkek (Djanibekova, 2020). Secondly, Kazakhstan was ready to agree to Armenia's accession only within the UN-established borders (i.e., without Nagorno-Karabakh), while with regard to Kyrgyzstan, a procedure of phased accession to customs regulation within the EAEU was to be used (Rakhaev et al., 2015, p.22). If these conditions were not met, Nazarbayev said Kazakhstan's further membership of the EAEU would be called in question. As a result, Armenia and Kyrgyzstan were admitted to the EAEU on Kazakhstan's conditions.

After signing the agreement on the EAEU, Kazakhstan began to put brakes on integration processes. For instance, it managed to secure exemptions to the liberalization of transport services in order to protect domestic carriers. As a result, in cooperation with Minsk, Astana blocked the creation of a single market of transport services in the EAEU territory (Roberts, 2016, p.549). Also, after the emergence of the idea of a supranational parliament of the EAEU, Nazarbayev warned that Kazakhstan might leave the organization, so the idea had to be shelved (Roberts, 2016, p.551).

\section{KAZAKHSTAN'S EXTERNAL OPPORTUNITIES AND RUSSIA'S PERCEPTION OF KAZAKHSTAN AS AN INDISPENSABLE PARTY IN EURASIAN INTEGRATION}

Throughout the entire period under review, Kazakhstan has been a key participant in Eurasian integration. Firstly, there are objective factors that make Kazakhstan an important participant in any integration projects in Russia. From a geographical point of view, the republic not 
only shares the longest border with Russia, but also serves as the key to integration with other Central Asian states. The integration of the subregion's countries with Russia is impossible without Kazakhstan's participation. In addition, the ideology of the Eurasian integration project and Eurasianism is closely linked with Kazakhstan and Nazarbayev personally (as one of those who was the first to propose a political union at least formally associated with Eurasianism). These factors are destined to last.

Secondly, Kazakhstan's non-participation during the creation of the EAEU would have disavowed the very idea of a Eurasian Union. Conceived as a union of three Eurasian states, it would have turned into another alliance of Russia and Belarus. At the moment of its creation, the EAEU was Russia's priority foreign policy project (Bordachev, 2015). In 2011, Vladimir Putin positioned a future EAEU as one of the centers of a multipolar world (Putin, 2011). All this made Kazakhstan an indispensable participant in Eurasian integration.

In addition, external opportunities resulting from Kazakhstan's non-participation in integration were unfavorable before the Treaty on the Customs Union came into force. By participating in the Customs Union, Kazakhstan had a chance to solve, and eventually solved, the problem of its security: of both oil and gas transit and of border regions with a significant Russian population. As a member of the Customs Union, Kazakhstan enjoyed long-term contracts for transiting oil and gas through Russian pipelines at preferential rates. The population's mobility and labor migration in the border regions was ensured. Moreover, Kazakhstan gained access to the Russian market for the goods of its enterprises, which favorably influenced non-primary exports from Kazakhstan to Russia (Migranyan, 2019, p.141).

However, after joining the Customs Union and the Common Economic Space, the external opportunities resulting from nonparticipation in further integration turned more favorable. On the one hand, Kazakhstan achieved the main goals of Eurasian integration: security and economic benefits were guaranteed. The main effect of integration for Kazakhstan's foreign trade was achieved already in 2011 (Migranyan, 2019, p.141). On the other hand, as early as 2013, some 
alternative options to Eurasian integration began to come to the fore. China's infrastructure projects are an example (Clarke, 2015).

External opportunities for Kazakhstan became noticeably more favorable after 2014. Firstly, the sanctions imposed on Russia harmed the Kazakh economy: the GDP growth rate in 2015 dwindled by 50 percent (Kazakhstan, 2015). Non-participation in the EAEU would mean a lesser impact of these sanctions on Kazakhstan's economy (Yefremenko, 2017). Secondly, the conflict between Russia, on the one hand, and the EU and the U.S., on the other, impedes the multi-vector policy that Kazakhstan has been pursuing since independence. Amid the remaining confrontation Kazakhstan has to move closer to one of the centers of power, thus jeopardizing relations with the others (Sullivan, 2019, p.31).

The external opportunities of Russia, as an established power, remained unfavorable throughout the entire period under review. It should be noted that Russia regards Eurasian integration primarily as a political project. Only $5 \%$ of Russia's trade turnover falls on the EAEU (Heller, 2019). Moreover, some researchers note that Russia's main goals in the EAEU are "collecting lands" and using the Union as "a counterweight to U.S. and Chinese incursions" (Kusznir, 2015; Dragneva and Wolczuk, 2014, p.14). Abandoning this project would be tantamount to giving up the ambitions to enjoy the role of one of the centers of power in a multipolar world. From this point of view, the urgency of deepening Eurasian integration merely soared after the beginning of confrontation with the West in 2014. Consequently, Russia's external opportunities have become even more unfavorable.

In general, it can be noted that throughout the entire period under review Kazakhstan remained an indispensable party in Eurasian integration. At the same time, the balance of external opportunities, initially unfavorable for Kazakhstan (during 2009-2012), eventually turned favorable (during 2013-2019).

\section{KAZAKHSTAN'S FOREIGN POLICY REGARDING EURASIAN INTEGRATION: THE RESULTS OF THE ANALYSIS}

Throughout the reviewed period Kazakhstan's foreign policy turned ever less "integrationist." Whereas at the moment the Customs Union 
was formed Kazakhstan was a firm proponent of deeper integration, its long-term aim being creation of a currency and political union at some future date, after the EAEU was brought into being its attitude to such plans made a U-turn.

In general, this change in foreign policy regarding integration allows us to distinguish two periods: before 2013-2014 and after. It is important to note that there is not a single event that could be called a "watershed." Crimea's reunification with Russia might have been such an event (as, for example, Holmquist, 2015 believes), but spokes had begun to be put in the wheels of the integration process before the Crimean events. For instance, take the amendments to the agreement on the EAEU Kazakhstan introduced at the end of 2013. Nevertheless, the Ukrainian crisis of 2014 markedly changed the external opportunities for Kazakhstan and Russia and unequivocally influenced the evolution of the country's policy towards integration.

The first period in the reviewed time span we are considering can be called a period when Kazakhstan actively invested into the development of Eurasian integration. On the one hand, its leadership was making proposals for further, deeper forms of integration, and showed fundamental readiness for them. On the other hand, Kazakhstan was ready to make concessions in order to create a Customs Union. All this characterizes Kazakhstan's foreign policy at this stage as an investment strategy in accordance with the model proposed by Kastner et al., 2016.

The other period was characterized not only by Kazakhstan's reluctance to invest into the integration association, but also by the strategy of extortion (hold-up) towards Russia. Kazakhstan rejected closer integration formats, and their implementation was stopped by various means, including through threats to leave the Eurasian Union. Moreover, Kazakhstan opposed the Union's expansion and agreed to it only when it found the terms favorable enough. These actions are nothing more than political extortion in relation to Russia.

The chosen model explains well the changes that occurred in Kazakhstan's strategy in the reviewed period. First, throughout the entire period Kazakhstan was perceived by Russia as an indispensable participant in integration. Its geographical position, the very essence 
of Eurasianism and the nature of the Union as an alliance of several states made Kazakhstan's participation crucial for the integration project to succeed.

Secondly, since the creation of the Customs Union, the balance of external opportunities has changed. Whereas during the creation of the Customs Union it was unfavorable for Kazakhstan and the country had to invest into the creation of an international regime, then over time, the external opportunities turned ever more favorable. Alongside the creation of this balance Kazakhstan's integration "zeal” easedthe better the opportunities resulting from no-participation in the integration association, the more resolutely Kazakhstan resisted deeper integration.

It can be concluded that while Kazakhstan remained as important as ever for the success of Eurasian integration, the changes of external opportunities became a factor for the evolution of the country's foreign policy. The achievement of integration's initial goals, the economic expansion of China into Central Asia, and the confrontation between Russia and the West made the balance of external opportunities favorable for Kazakhstan. This prompted the country to change its strategy of investing into building and developing the Eurasian Union in favor of extorting preferences and concessions from Russia as a condition for further participation in the integration project.

In this context, the Russian leadership has several options to choose from: to make more concessions and offer preferences to Kazakhstan in order to deepen Eurasian integration or to diversify its policy on the integration track, thus stripping Kazakhstan of its image of an indispensable actor. Both approaches have significant flaws: for example, additional concessions and preferences to one actor in an integration association would lead to demands for similar concessions from other EAEU members, which is economically and politically disadvantageous for Russia. On the other hand, it is possible to diversify policies inside the EAEU only by including new members, comparable with Kazakhstan in importance. However, at this moment, no possibility of counterbalancing Kazakhstan in the EAEU by a new member state is in sight. 
For Russia, it seems reasonable to consider ways of deepening the EAEU and transforming it from a mostly political project into a truly economic and integrational one, which would make nonparticipation more unfavorable for other countries. At the same time, it should be noted that Russia should also revise its policy towards Kazakhstan itself, using not only political and economic instruments of influence, but also measures to deepen interaction with the Russian-speaking population that might act as a natural Russian soft power agent. Such a policy can impose certain internal restrictions on Kazakhstan's foreign policy.

It is worth noting that the approach we used is true only within certain limits. The Kastner et al model allows for characterizing and explaining only Kazakhstan's general foreign policy strategy within the framework of Eurasian integration, but not individual actions taken by the state. Therefore, this model is unable to accurately explain and cover the entire range of Kazakhstan's foreign policy instruments.

To obtain more accurate results, in the future it is necessary to clarify the factors influencing the variables in the model: "the balance of external opportunities" and "perception of indispensability." In addition, it may be worth complementing the model with some domestic political variables, in the first place, which is primarily used in neoclassical realism as the "intervening variable."

\section{References}

Akimbekov, S., 2014. Needless Rush. Russia in Global Affairs, 12(4) [online]. Available at: $<$ https://eng.globalaffairs.ru/articles/needless-rush/ $>$ [Accessed 28 March 2020].

Ambrosio, T. and Lange, W., 2015. Mapping Kazakhstan's Geopolitical Code: An Analysis of Nazarbayev's Presidential Addresses, 1997-2014. Eurasian Geography and Economics, 55(5), pp.537-559.

Anceschi, L., 2014. Regime-Building, Identity-Making and Foreign Policy: NeoEurasianist Rhetoric in Post-Soviet Kazakhstan. Nationalities Papers: The Journal of Nationalism and Ethnicity, 42(5), pp.733-749. 
Bagdasaryan, K. and Pakhomov, A., 2016. Problemy uchastiya gosudarstv EAES v deyatel'nosti VTO [Problems of the EEU States' Participation in WTO Activities]. Ekonomicheskoe razvitie Rossii, 23(11), pp.31-37.

Bhutia, S., 2019. Russia Dominates Eurasian Union Trade. Here Are the Numbers. Eurasianet, 18 October [online]. Available at: <https://eurasianet. org/russia-dominates-eurasian-union-trade-here-are-the-numbers $>$ [Accessed 21 March 2020].

Bordachev, T. V., 2015. New Eurasian Momentum. Russia in Global Affairs, 13(4) [online]. Available at: <https://eng.globalaffairs.ru/articles/new-eurasianmomentum/> [Accessed 28 March 2020].

Clarke, M., 2015. Kazakhstan's Multi-Vector Foreign Policy: Diminishing Returns in an Era of Great Power "Pivots"? The ASAN Forum, 9 April [online]. Available at: $<$ http://www.theasanforum.org/kazakhstans-multi-vector-foreignpolicy-diminishing-returns-in-an-era-of-great-power-pivots/> [Accessed 20 March 2020].

Concept, 2014. Ukaz Prezidenta Respubliki Kazahstan No. 741 "O Kontsepcii vneshnei politiki Respubliki Kazahstan na 2014 - 2020 gody" ot 21 yanvarya 2014 g. [Decree of the President of the Republic of Kazakhstan \#741 "The Concept of Foreign Policy of the Republic of Kazakhstan for the Period of 2014 - 2020" as of January 21, 2014]. Zakon.kz, 21 January [online]. Available at: $<$ https://online.zakon.kz/Document/?doc_id=31498994\#pos=18;-52> [Accessed 20 March 2020].

Dragneva, R. and Wolczuk, K., 2014. Eurasian Economic Integration: Institutions, Promises and Faultlines. LSE IDEAS Special Report, SR019, pp.8-15.

Djanibekova, N., 2020. Kyrgyzstan-Kazahstan: pogranichnyī krizis oslozhnyaetsya vzaimnym nedoveriemn [Crisis on the Kyrgyz-Kazakhstan Border Is Exacerbated by Mutual Mistrust]. Eurasianet, 8 February [online]. Available at: $<$ https://russian.eurasianet.org/\%D0\%BA\%D1\%8B\%D1\%80\%D 0\%B3\%D1\%8B\%D0\%B7\%D1\%81\%D1\%82\%D0\%B0\%D0\%BD-\%D0\%BA\% D0\%B0\%D0\%B7\%D0\%B0\%D1\%85\%D1\%81\%D1\%82\%D0\%B0\%D0\%BD\%D0\%BF\%D0\%BE\%D0\%B3\%D1\%80\%D0\%B0\%D0\%BD\%D0\%B8\%D1\%87 \%D0\%BD\%D1\%8B\%D0\%B9-\%D0\%BA\%D1\%80\%D0\%B8\%D0\%B7\%D0\%B 8\%D1\%81-\%D0\%BE\%D1\%81\%D0\%BB\%D0\%BE\%D0\%B6\%D0\%BD\%D1\% 8F\%D0\%B5\%D1\%82\%D1\%81\%D1\%8F-\%D0\%B2\%D0\%B7\%D0\%B0\%D0\% B8\%D0\%BC\%D0\%BD\%D1\%8B\%D0\%BC-\%D0\%BD\%D0\%B5\%D0\%B4\%D0 \%BE\%D0\%B2\%D0\%B5\%D1\%80\%D0\%B8\%D0\%B5\%D0\%BC> [Accessed 18 March 2020]. 
Gusev, L. Yu., 2015. Osnovnye napravleniya sotrudnichestva mezhdu Rossiey i Kazahstanom v ramkah evraziīskoy integratsii [Major Areas of RussiaKazakhstan Cooperation in Eurasian Integration]. Journal of International Analytics, (1), pp.93-104 [online]. Available at: $<$ https://doi.org/10.46272/25878476-2015-0-1-93-104> [Accessed 27 August 2020].

Kheifets, B., 2015. Evrazī̄skiī ekonomicheskiī soiuz: novye vyzovy dlya biznesa [Eurasian Economic Union: New Challenges for Business]. Obshchestvo $i$ ekonomika, No.6, pp.5-22.

Heller, R., 2019. From Community Politics to the Politicization of Community: The Role of Identity in Eurasian Economic Integration. East European Politics, 35(2), pp.122-142. DOI: 10.1080/21599165.2019.1610879.

Holmquist, E., 2015. Kazakhstan After Crimea: 'You Cannot Choose Your Neighbors. RUFS Briefing, pp.1-2.

Isaacs, R., 2020. Russia-Kazakhstan Relations and the Tokayev-Nazarbayev Tandem. Russian Analytical Digest, 248, pp.2-5.

Kassen, M., 2018. Understanding Foreign Policy Strategies of Kazakhstan: A Case Study of the Landlocked and Transcontinental Country. Cambridge Review of International Affairs, 31(3-4), pp. 314-343.

Kastner, S. L., Pearson, M. M. and Recto, C., 2016. Invest, Hold Up, or Accept? China in Multilateral Governance. Security Studies, 25, pp.142-179. DOI: 10.1080/09557571.2018.1520809.

Knobel, A., 2015. Yevraziīskiy ekonomicheskiy soyuz: perspektivy razvitiia i vozmozhnye prepyatstviya [The Eurasian Economic Union: Development Prospects and Possible Obstacles]. Voprosy ekonomiki, 3, pp.87-108.

Krasner, S. D. (ed.), 1983. International Regimes. Ithaca: Cornell University Press.

Kusznir, J., 2015. Russia’s Borders: Moscow's Long Alliance with Kazakhstan Is Strong but Not Unbreakable. The Conversation, 20 January. [online]. Available at: $<$ https://theconversation.com/russias-borders-moscows-long-alliance-withkazakhstan-is-strong-but-not-unbreakable-36457> [Accessed 28 March 2020].

Laruelle M., Royce, D., and Beyssembayev, S., 2019. Untangling the Puzzle of "Russia's Influence" in Kazakhstan. Eurasian Geography and Economics, 60(2), pp.211-243. DOI: 10.1080/15387216.2019.1645033.

Laruelle, M., 2015. Kazakhstan's Posture in the Eurasian Union: In Search of Serene Sovereignty. Russian Analytical Digest, 165, pp.7-9. 
Libman, A., 2018. A Eurasian Economic Union: Between Perception and Reality. New Eastern Europe, 9 January [online]. Available at: <https://neweasterneurope. eu/2018/01/09/8767/> [Accessed 20 March 2020].

Lillis, J., 2015. Kazakhstan: Astana Faces Up to Economic Doom and Gloom. Eurasianet, 19 January [online]. Available at: $<$ https://eurasianet.org/kazakhstanastana-faces-up-to-economic-doom-and-gloom> [Accessed 20 March 2020].

Malysheva, D. B., 2016. Kazakhstan i Rossiya: problemy vzaimodejstviya [Kazakhstan and Russia: Problems of Interaction]. IMEMO, 7 September [online]. Available at: <https://www.imemo.ru/index.php?page_ $\mathrm{id}=502 \& \mathrm{id}=2573 \& \mathrm{ret}=640>$ [Accessed 20 March 2020].

Mansurov, T. 2008 Integratsionny vektor yevraziīskoy politiki [Integration Vector of Eurasian Politics]. Politicheskī klass, 8, pp.22-29.

Migranyan, A. A., 2019. Kazakhstan v EAES: torgovo-ekonomicheskie effekty [Kazakhstan in the EAEU: Trade and Economic Effects]. Vestnik Instituta ekonomiki Rossīiskoi akademii nauk, 4, pp.134-153.

Morozov, V., 2015. Kazahstan i "russkiy mir" [Kazakhstan and the "Russian World"]. PONARS Evraziya, 364, pp.1-8.

Nazarbaev, N., 2011. Yevraziīsky Soyuz: ot idei k istorii budushchego [The Eurasian Union: From an Idea to the Story of the Future]. Izvestiya, 25 October [online]. Available at: http://izvestia.ru/news/504908> [Accessed 20 March 2020].

Nazarbaev, 2014. Nazarbaev ugrozhaet, chto Kazahstan mozhet pokinut' Yevraziīsky soyuz [Nazarbayev Threatens Kazakhstan May Leave the Eurasian Union]. Pravda.ru, 31 August [online]. Available at: <https://www.pravda.ru/ news/world/1223956-kaz/> [Accessed 20 March 2020].

Nurgalieva, L., 2016. Kazakhstan's Economic Soft Balancing Policy vis-à-vis Russia: From the Eurasian Union to the Economic Cooperation with Turkey. Journal of Eurasian Studies, 7(1), pp.92-105.

Putin, V., 2011. Novy integracionny proekt dlya Yevrazii-budushchee, kotoroe rozhdaetsa segodna [New integration project for Eurasia-The Future That Is Born Today]. Ekho Moskvy, 4 October [online]. Available at: <https://echo.msk. ru/blog/statya/817588-echo/> [Accessed 20 March 2020].

Rakhaev, B., Kalabekova, K., \& Gazaeva, M., 2014 Strategicheskie tseli novyh form integratsii na postsovetskom prostranstve [Strategic goals of new forms of integration in the post-Soviet space]. Obshchestvo i ekonomika, 10, pp.5-30. 
Rahmatulina, G, 2010. Tamozhennyī soyuz v ramkah EvrAzES: perspektivy dlia Kazahstana [Customs Union within EurAsEC: prospects for Kazakhstan]. Mirovaya ekonomika i mezhdunarodnye otnosheniya, 11, pp.75-81.

Roberts, S. P. and Moshes, A., 2016. The Eurasian Economic Union: a case of reproductive integration? Post-Soviet Affairs, 32(6), pp.542-565.

Roberts, S. R., 2015 The Ukraine Conflict and the Future of Kazakhstan's MultiVector Foreign Policy. PONARS Eurasia Policy Memo, 388, pp.1-6.

Skriba, A.S., 2015. Politika balansirovaniya na postsovetskom prostranstve na primere Belorussii i Ukrainy. [Balancing Policy in the Post-Soviet Space: Cases of Belarus and Ukraine.] PhD Dissertation, NRU-HSE.

Sullivan, C. J., 2019 End of an Era? Kazakhstan and the Fate of Multivectorism. In: Caron J.-F. (ed.). Kazakhstan and the Soviet Legacy. Singapore: Palgrave Macmillan. pp.31-50.

Today.kz., 2015. V ramkah EAES budet sozdan obstchy rynok nefti, gaza i nefteproduktov [A Common Market for Oil, Gas, and Petroleum Products Will Be Created within the EAEU]. Today.kz, 22 April [online]. Available at: <https://web.archive.org/web/20181227155719/http://today.kz/news/ ekonomika/2015-04-22/612061-v-ramkah-eaesbudet-sozdan-obsij-rynok-neftigaza-i-nefteproduktov/> [Accessed 20 March 2020].

Treaty, 2014. "Dogovor o Yevrazī̄skom ekonomicheskom soyuze" ot 29 maya, 2014 g.[ "Treaty on the Eurasian Economic Union" as of May 29, 2014] Yevrazīiskaya ekonomicheskaya komissiya, 29 May [online]. Available at: $<\mathrm{https} / /$ docs.eaeunion.org/ru-ru/Pages/DisplayDocument.aspx?s=bef9c798-3978-42f39ef2-d0fb3d53b75f\&w=632c7868-4ee2-4b21-bc64-1995328e6ef3\&l=540294aec3c9-4511-9bf8-aaf5d6e0d169\&EntityID=3610> [Accessed 20 March 2020].

Turkey and China, 2015. Turciya i Kitaī dogovorilis' dostavlyat' gruzy v Evropu v obhod Rossii [Turkey and China Have Agreed to Deliver Goods to Europe Bypassing Russia]. Lenta.ru, 30 November [online]. Available at: $<$ https://lenta. $\mathrm{ru} /$ news/2015/11/30/transkasp/> [Accessed 20 March 2020].

Yefremenko, D. V., 2017 The Birth of a Greater Eurasia. Russia in Global Affairs, 15(1) [online]. Available at: <https://eng.globalaffairs.ru/articles/the-birth-ofa-greater-eurasia/> [Accessed 20 March 2020]. 